\title{
八代市およびその周辺地域の日奈久断層系による地震被害想定 DAMAGE PREDICTION OF YATSUSHIRO CITY AND ITS VICINITY DUE TO A HYOPTEHSIZED HINAGU FAULT EARTHQUAKE
}

\author{
川瀬 博*, 増田有周** \\ Hiroshi KAWASE and Arichika MASUDA
}

\begin{abstract}
We estimate building damage in Yatsushiro City and its vicinity by using predicted strong motions for hypothesized rupture scenarios along the Hinagu fault and our vulnerability functions. Since the basin structure of the target area was not constructed yet, we estimate it based on boring databases and S-wave velocity structures determined by $\mathrm{H} / \mathrm{V}$ ratios of microtremors at several points inside the basin. Assuming shallow and deep basin structure we use our hybrid simulation technique to estimate broadband strong motions and building damage by using both nonlinear models and vulnerability functions. The result of our simulation shows that we have to prepare for a severe disaster along the hypothesized fault in Yatsushiro City.
\end{abstract}

Keywords : Hybrid method, basin structure, strong motion prediction, damage prediction, vulnerability function ハイブリッド法, 盆地構造, 強震動予測, 被害予測, 被害関数

\section{1.はじめに}

都市防災研究において、内陸直下型地震における建物被害を想定 するためには、地震動を精度よく推定することが必要となる。地震 学的知見を生かした定量的な強震動予測に関する研究は兵庫県南部 地震以降急速に発展を遂げ、低周波数から高周波数までの広周波数 帯域の予測には八イブリッド法が優れていることが多く報告されて

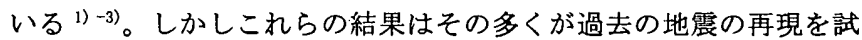
みたものであり、未だ発生していない地震の予測例の報告は、政府 の地震調査研究推進本部が実施中のものを除くと極めて限られてい

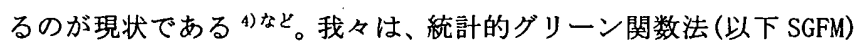
と三次元有限差分法 (3D-FDM) を組み合わせたハイブリッド法を用い て、福岡市直下を横切る警固断層による強震動評価を行い ${ }^{5)}$ 、さら に兵庫県南部地震の被害統計で較正した被害予測用建物群モデル ${ }^{6)}$ -8) を用いて発生被害の予測を行った ${ }^{9)}$ 。その結果、万一活動した場 合には福岡市街中心部に大きな被害が出るであろうことを予測して いる。しかし、この警固断層の活動度は $\mathrm{B}$ 級と $\mathrm{C}$ 級の中間的レベル で、今後 30 年間に発生する確率は $0.4 \%$ と見積られている。

これに対して、2002 年 5 月に地震調查推進本部の発表した熊本県 の布田川一日奈久断層帯の地震発生確率 (長期評価) は、今後 30 年以 内で最大 $6 \%$ とされており ${ }^{10)}$ 、不確実性はあるものの日本の活断層 の中でも「地震発生確率の高いグループ」に属する。この発生確率 忕州ではこれまでのところ最大であるにもかかわらず、未だこの 地震に対する被害推定はなされていない。そこで我々は同じハイブ リッド法によりまず強震動評価を行い、それを用いて熊本市および 八代市域の建物被害率を予測することにした。その際、兵庫県南部 地震の被害率から評価された被害予測用建物群を用いて得られた被
害関数 ${ }^{11)}$ を用いて、建物種別毎に簡便に広域の被害想定を行い、詳 細評価の場合と比較してその得失を論じた。

\section{2. 方法}

内陸直下型地震による建物被害を想定するためには、地震動を精度 よく推定し、その地震動によって受ける建物被害を定量的に推定す る必要がある。本研究では、北部・中部・南部の 3 セグメントのう ち、動く確率の高いとされている日奈久断層中部付近の、熊本市・ 八代市、およびその周辺地域を被害想定領域として設定し、まず統 計的グリーン関数法 (SGFM) と 3 次元有限差分法 (3D-FDM) のハイブリ ッド法により強震動評価を行う。この予測強震動波形を用いた被害 予測に関しては長戸・川瀬. ${ }^{6}$ )-8)により、兵庫県南部地震の被害率 (以 下本論文でいう被害率とは大破・崩壊率) と松島・川瀬 ${ }^{12)}$ の求めた 再現強震動から、被害予測用の建物群モデルが RC 造、鉄骨造、木造 建物について構築されているので、このモデルに観測強震動を入力 して地震応答解析を行い、熊本市・八代市およびその周辺地域での 建物被害率を求めるとともに、強震動の強度指標と対态させて構筑 した被害関数 ${ }^{11)}$ によっても被害率を求め、上記の応答解析から求め た被害率と比較し考察する。

\section{3. 強震動評価}

最初に日奈久中部断層による強震動を評価する。ここで用いたハ イブリッド法は中道・川瀬 $(2002)^{5)}$ と同じもので、理論的計算に用 いる三次元盆地構造と統計的グリーン関数法に用いる S 波速度 $1 \mathrm{~km} / \mathrm{sec}$ より上の一次元構造が必要となる。さらにハイブリッド合 成をしたあと表層の増幅を考慮するために表層構造も必要となる。
* 九州大学人間環境学研究院 教授 $\cdot$ 工博

** 清水建設(侏) 工修

(元 九州大学大学院)
Prof., Faculty of Human-Environment Studies, Kyushu Univ., Dr. Eng.

Shimizu Corporation, M. Eng.

(Graduated from Kyushu Univ.) 
以下では、まず強震動評価に必要な地盤モデルと震源モデルについ て記述し、そのモデルによって得られた予測強震動を示す。

\section{1 解析対象領域の設定}

対象とする領域は、日奈久断層に沿って平野部が広がっている西 側の地域とし、熊本市から八代市に及ぶ地域とする。基準点を緯度 $\left(32.402^{\circ}\right)$ 、経度 $\left(130.286^{\circ}\right)$ に取り、この点から北に $64 \mathrm{~km}$ 、西に $26.4 \mathrm{~km}$ の領域を設定して、断層に平行になるよう北から時計回りで $35.06^{\circ}$ 回転させた領域とする。この領域の長さは、ディレクティビ ティが顕著に現れる大振幅地域が含まれるように、断層全長に前後 $8 \mathrm{~km}$ 程度を加えたものとし、また人口密度の高い熊本市中心部が含 まれるように領域の幅と位置に配慮した。なお解析領域の全体サイ ズは 3 次元 FDMの計算時間で制約され、少なくとも深さ $20 \mathrm{~km}$ まで はモデル化する必要があることから、2003年時点ではこのサイズ(解 析メモリで約 6GB)が我々にとってほぼ限界となっている。

日奈久断層中部は 3 セグメントにモデル化する。北部(北端： $32.722^{\circ} \mathrm{N}, 130.786^{\circ} \mathrm{E}$ 、南端：32.581 $\mathrm{N}, 130.710^{\circ} \mathrm{E}$ 、長さ：約 $17.1 \mathrm{~km}$ )、中部 (北端 : $32.578^{\circ} \mathrm{N}, 130.701^{\circ} \mathrm{E}$ 、南端 : $32.487^{\circ} \mathrm{N}$, $130.637^{\circ} \mathrm{E}$ 、長さ：約 $11.7 \mathrm{~km}$ )、南部 (北端： $32.487^{\circ} \mathrm{N}, 130.637^{\circ}$ E、南端：32. $379^{\circ} \mathrm{N}, 130.510^{\circ} \mathrm{E}$ 、長さ：約 $17.0 \mathrm{~km}$ ) と仮定し、北 から南まで総延長約 $46 \mathrm{~km}$ の断層として設定した。断層の設定にあた っては新編「日本の活断層」 ${ }^{13)}$ おび地震調査研究推進本部の情報 10)を参考とした。解析対象領域を図 1 に示す。
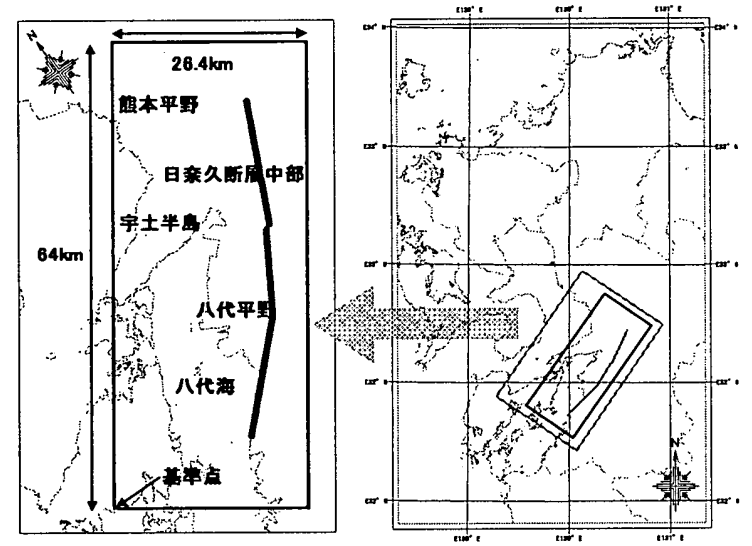

図 1 解析対象領域と日奈久断層

\section{2 地盤構造の推定}

日奈久断層における強震動予測のため地盤構造を推定する。我々 は 2002 年 9 月 29 日と 30 日に、熊本八代平野において常時微動計測 を行った。この微動観測記録を解析し、地盤の H/V スペクトルを求 める。近年、単点観測データの $\mathrm{H} / \mathrm{V}$ スペクトルの周期特性を Rayleigh 波の理論 H/Vに合わせることにより地盤構造を推定する研究成果が 発表されており 14)15)、ここでもその方法を用いる。まず八代平野の 基準 S 波地盤構造を設定する。表層地盤については K-NET 観測点 KMM012 (八代市役所) と相似な構造を全域に仮定し、深層地盤につい ては同じような地盤環境と推定される KiK-net 観測点 KMMH16 (益城) の構造を参照速度構造として用いる。

微動計測の結果から 1 秒以下の短周期成分の H/Vのピークは顕著
だったものの長周期成分についてはその振幅レベルが低く、ピーク がはっきりしなかったため、川瀬・原田 $(2002)^{16}{ }^{16}$ が得た KMM012 地点 での地震波の coda 部分(S 波よりもずっと後の表面波部分)による $\mathrm{H} / \mathrm{V}$ を使って深層地盤の層厚を求め、一方表層地盤については我ヶ の微動計測で得た微動の H/V を使って、まず KMM012 に扝ける地盤の $\mathrm{S}$ 波速度構造を求めた。そのフィット状況を図 2 に、求めた KMM012 のS 波速度構造を図 3 に示す。なおここで理論の $\mathrm{H} / \mathrm{V}$ はVのゼ口点 でピークとなるので振幅は無限大となるが、観測值では有限となっ ている。この速度構造を基淮として実施した微動観測点各点の地盤

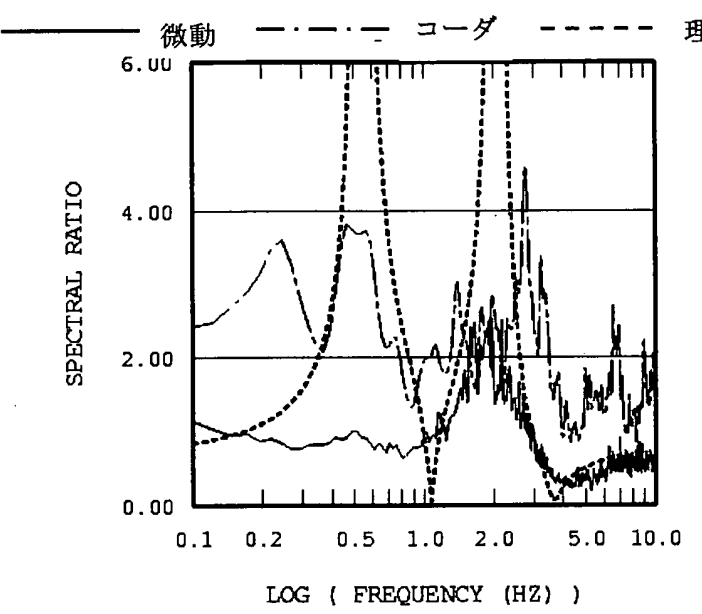

図 2 KMM012(八代市役所)におけるコーダ波と微動の H/V と Rayleigh 波の理論 H/V 比との比較

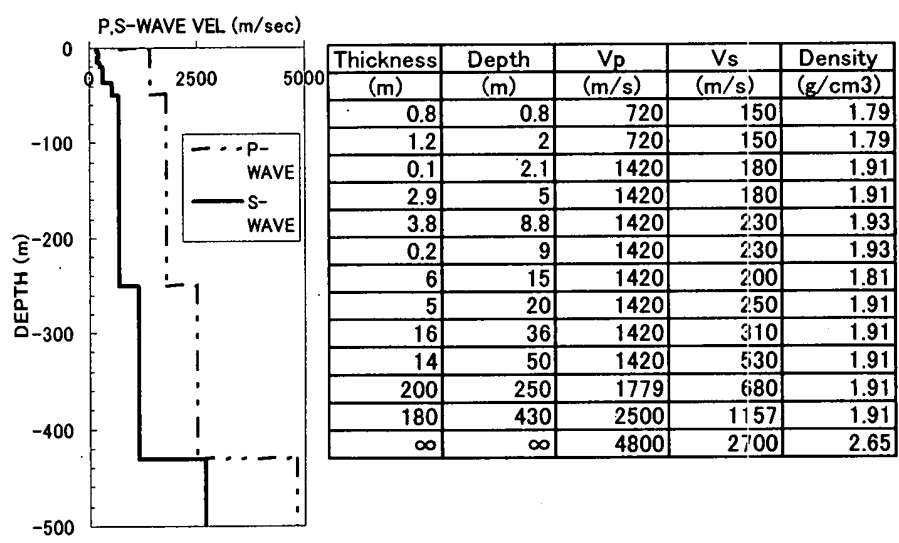

図 3 KMM012における推定した基準地盤棈造

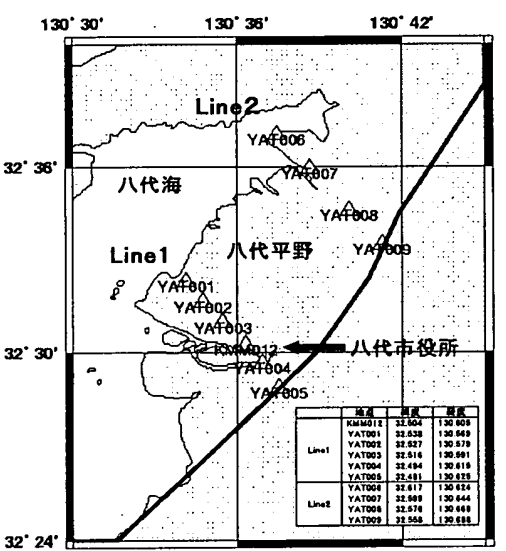

図 4 常時微動計測の観測点 

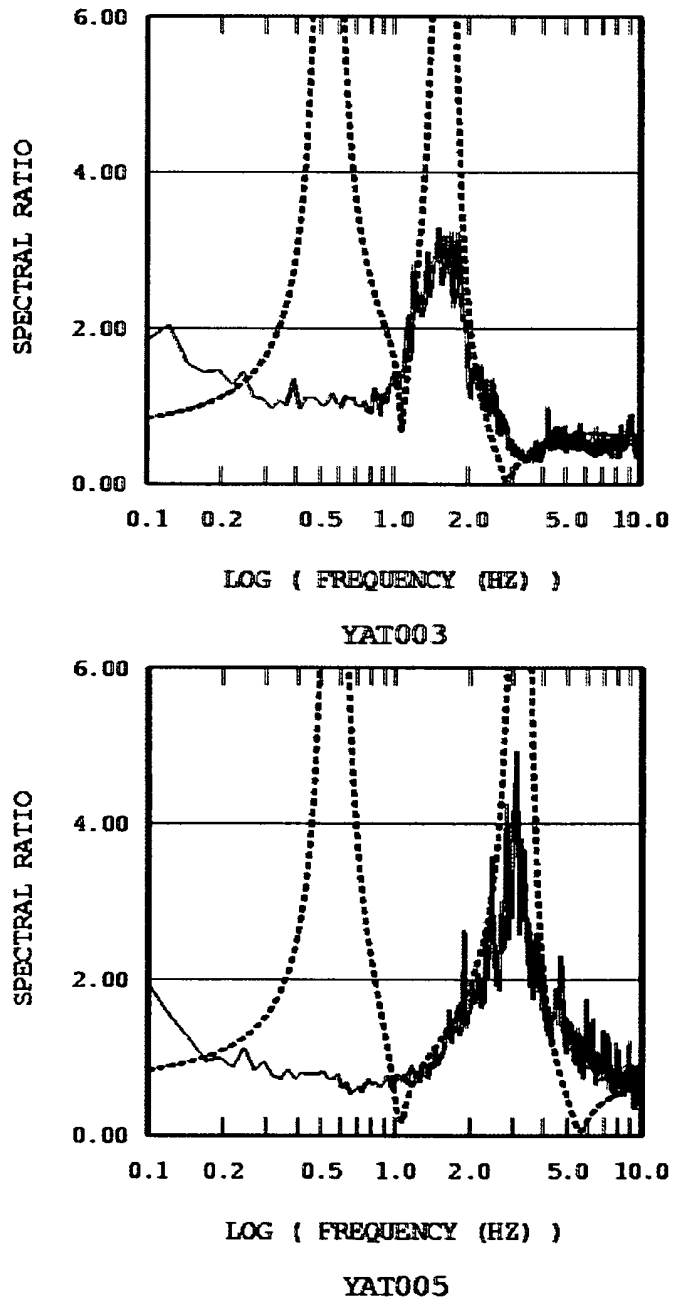

図 5 八代市内の微動穊測点における $\mathrm{H} / \mathrm{V}$ と理論 $\mathrm{H} / \mathrm{V}$ の比較
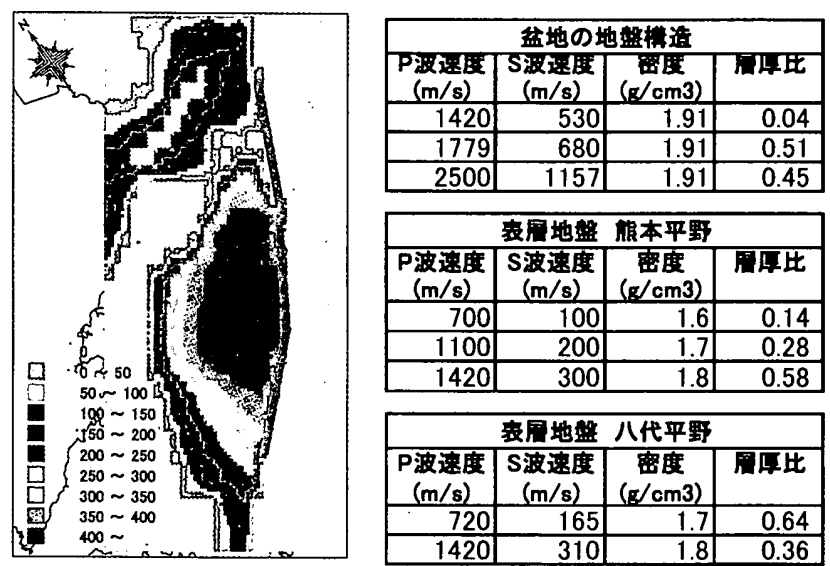

\begin{tabular}{|c|c|c|c|}
\hline \multicolumn{4}{|c|}{ 表局地盤 八代平野 } \\
\hline $\begin{array}{c}\text { P波速度 } \\
(\mathrm{m} / \mathrm{s})\end{array}$ & $\begin{array}{c}\text { S波這度 }_{(\mathrm{m} / \mathrm{s})}\end{array}$ & $\begin{array}{c}\text { 密度 } \\
\left(\mathrm{g} / \mathrm{cm}^{2}\right)\end{array}$ & 凰厚比 \\
\hline 720 & 165 & 1.7 & 0.64 \\
\hline 1420 & 310 & 1.8 & 0.36 \\
\hline
\end{tabular}

図 $6 \mathrm{Vs}=\mathbf{2 , 7 0 0 \mathrm { m } / \mathrm { s }}$ の層の上面深さ $(\mathrm{m})$ と推定地盤樮造

構造を推定した。図 4 に実施した八代市の微動観測点位置を、図 5 にその $\mathrm{H} / \mathrm{V}$ のイット状況の例を 2 地点について示寸。

これらの結果と、防災科学研究所の深部地盤モデルの資料 ${ }^{17) 、}$ 、地 震調查推進本部の染部構造の情報 ${ }^{18}$ 、おおよび(社) 熊本県地質調查業 協会で収集したボーリングデータ、PS 検層データを参考にして解析 領域における地盤モデルを構筑した。得られた盆地構造の深さコン ターと速度構造を図 6 に示す。ここで各層の層厚は盆地の深さに比

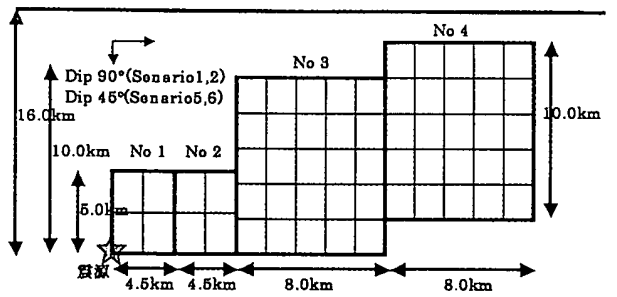

\begin{tabular}{|c|c|c|c|c|c|c|c|}
\hline Asperity NO & $\begin{array}{c}\text { Mo } \times 10^{18} \\
(\mathrm{~N} \times \mathrm{m})\end{array}$ & $\begin{array}{c}\text { SIZE } \\
(\mathrm{km} \times \mathrm{km})\end{array}$ & $\begin{array}{c}\text { D0 } \\
(\mathrm{m})\end{array}$ & Dip & $\mathrm{C}$ & $\mathrm{N}$ & $\begin{array}{c}\tau \\
(\mathrm{sec})\end{array}$ \\
\hline 1 & 0.62 & $4.5 \times 5$ & 0.85 & $90^{\circ}$ & 0.9 & 2 & 0.6 \\
\hline 2 & 1.07 & $4.5 \times 5$ & 1.47 & $90^{\circ}$ & 1.56 & 2 & 0.6 \\
\hline 3 & 2.59 & $8 \times 10$ & 1 & $90^{\circ}$ & 0.53 & 5 & 0.6 \\
\hline 4 & 4.83 & $8 \times 10$ & 1.9 & $90^{\circ}$ & 1.01 & 5 & 0.6 \\
\hline
\end{tabular}

図 7 松島・川瀬の震源モデルに鹪执したシナリオ $1 \& 2$ (C, N, ては応力降下量比、時間軸の重ね合わせ数、および すべりの継続時間で、統計的グリーン関数法でのみ使用)

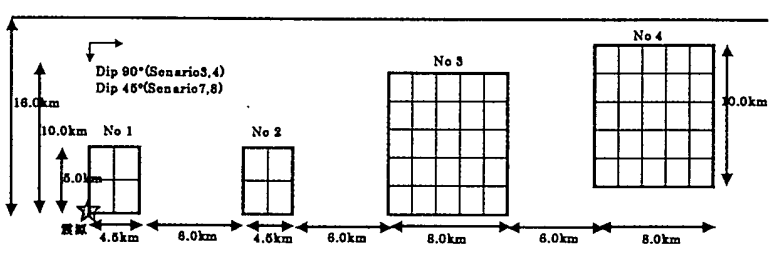

図 8 日奈久断層全体に分布させたシナリオ $3 \& 4$

例させており、図にはその層厚比を示した。なお表層地盤の減衰は $2 \%$ と、深部地盤には速度に応じた振動数反比例型减衰を与えた。

\section{3 震源モデルと破壊シナリオ}

これまでの研究によって、定量的被害予測のためには震源破壊の 不均一性を考えることが不可欠であることがわかっている。ここで は、最近 50 年間において最大の被害をもたらした兵庫県南部地震の 震源破壊過程を中規模内陸地震の典型として考え、その神戸側セグ メントの震源破壊モデルである松島・川瀬 $(2000)^{11)}$ の 4 アスペリテ イモデル(図 7)を基本的な破壊シナリオと設定した。その断層の南 端を震源 (発震点) として同じ 4 アスペリティを仮定した場合 (Scenario1)、同様に北端を震源とした場合 (Scenario2)、南端を震 源とし4アスペリティを断層全体に分布させた場合 (Scenario3)、同 様に北端を震源とした場合(Scenario4)の 4 シナリオを考え、さらにこ れらのアスペリティ配置はそのままにして破壊開始点を第 3 アスペリ ティと第4アスペリティの間にした Scenario 5〜Scenario 8 を設定し た。この 8 シナリオ全てに対し、日奈久断層がかなりの上下オフセット (正断層成分)を伴っていることから、各シナリオのすべり角を繸ずれと 横ずれが 1:1 となる $135^{\circ}$ としたScenario 1d〜Scenario 8d を設定し、 都合 16 シナリオの強震動評価を行った。なお、すべり角がある場合に は放射特性が変化し、純横ずれの場合よりも直上での地震動が増大する ことがあるので検討の対象としたものである。

\section{4 予测强震動}

中道・川瀬 $(2002)^{1)}$ は、高振動数域を SGFMで、1.75Hzよりも低 振動数域を 3D-FDM で計算し、それらを組み合わせるハイブリッド 法を用いて兵庫県南部地震による強震動の再現および仮想福岡地震 の強震動予測を行い、良好な結果を得ている。本研究でもこれと同 じ手法で、解析領域を $400 \mathrm{~m}$ のメッシュに細分し(ただし FDM のメ ッシュは 80m)各メッシュの中心点の強震動を評価した。SGFM では 伊藤・他 ${ }^{19)}$ が抽出した統計的経時特性とスペクトル特性に基づき、 
まず Vs=1,070m/s の露頭層での波形を計算し、さらに本論文におい て工学的基盤と見なす $\mathrm{Vs}=530 \mathrm{~m} / \mathrm{s}$ の層の波形を一次元重複反射理論 により計算した。3D-FDM も $\mathrm{Vs}=530 \mathrm{~m} / \mathrm{s}$ の層までモデル化して Graves $(1996)^{20)}$ の FDM コードで計算し、そのレベルでマッチン グ周波数を $1.75 \mathrm{~Hz}$ としてハイブリッド合成を行い、最後に図 6 右に 示した熊本・八代平野の表層地盤構造をもとに、地表面波形を再び 一次元重複反射理論で計算した。なおこれら一次元重複反射理論の 計算では入射角の影響は小さいとしてすべて鉛直入射を仮定してい る。最も広域に大加速度領域が分布した Scenario 3 を代表として、 その最大加速度 PGA および最大速度 PGVの分布および代表地点(八 代市役所と熊本市役所)での速度波形、加速度フーリエスペクトルを 図 9・図10に示寸。この図から、断層に近い八代市役所では $100 \mathrm{~cm} / \mathrm{sec}$ を超える卓越振動数約 $1 \mathrm{~Hz}$ の大振幅速度パルスを有する地震動が生 じることがわかる。これは予測強震動が兵庫県南部地震での観測強 震動と同じ性質を有しているということを意味しており、同じアス ペリティを仮定した当然の帰結であるが、Scenario3では分布を幅広 くしたことにより、最も近接した第一アスペリティからのパルスが 最大振幅となり、他のアスペリティからの寄与が相対的に小さくな っているという特徵が得られている。また盆地の染さも神戸より浅 いので表層の影響で $2 \mathrm{~Hz}$ 付近が卓越している波形となっている。

震源プロセスの違いによる影響を見るために全 16 シナリオによ

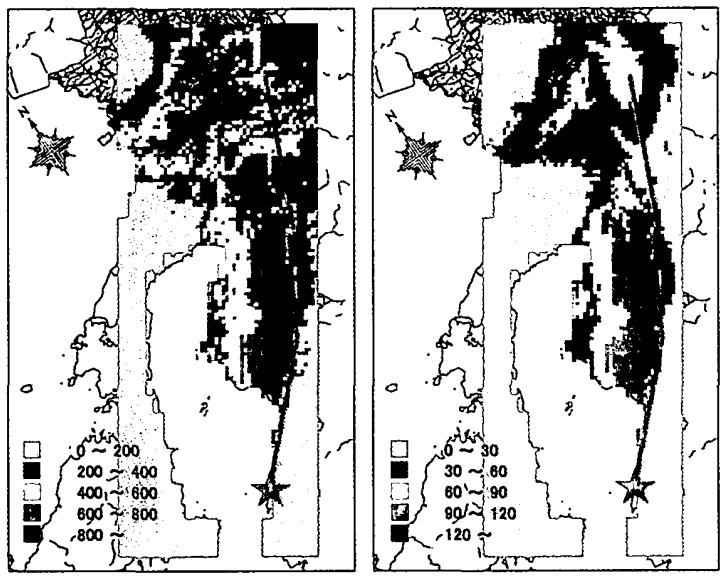

図 9 Scenario3 の PGA(左 : gal) と PGV(右 : cm/sec) 分布
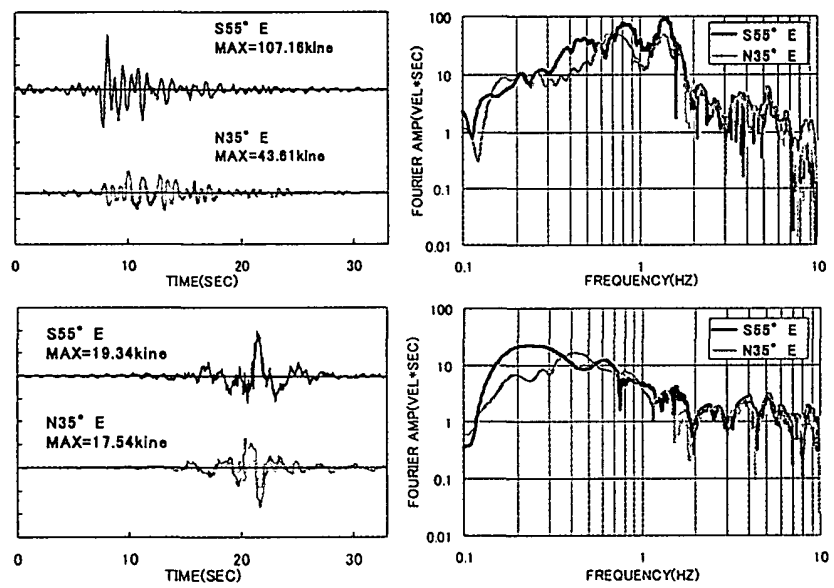

図 10 Scenario3 の予測強震動特性(上 : 八代市役所下 : 熊本市役所)

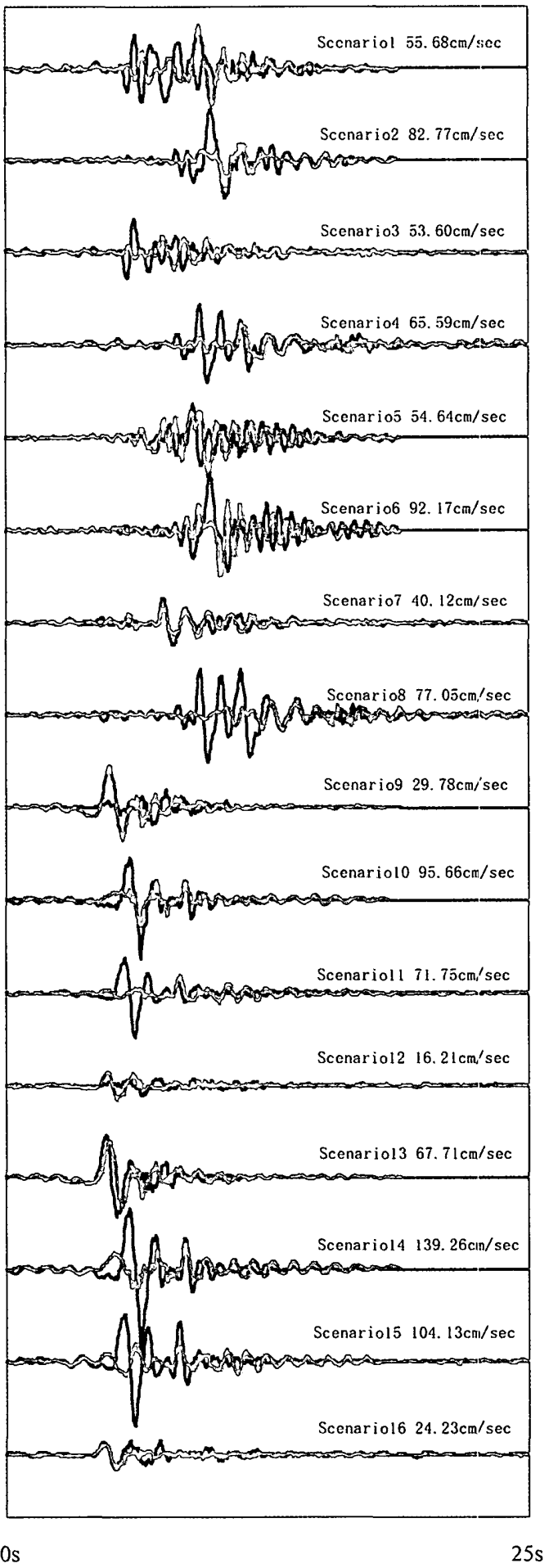

図 11 八代市役所における工学的基盤上での速度波形 $(\mathrm{cm} / \mathrm{sec})$ (上から順に Scenario1〜16, 青が $\mathrm{FN}=\mathrm{S55}^{\circ} \mathrm{E}$ ，赤が $\mathrm{FP}=\mathrm{N} 35^{\circ} \mathrm{E}$ )

る八代市役所での工学的基盤上での予測波形を比較して図 11 に示 す(表示した值は断層直交成分の PGV)。この図からシナリオによっ て波形にはかなりの違いが生じるが、多くの場合大振幅速度パルス が生成されることがわかる。Scenario9〜16の縦ずれ成分を有する場 合は、観測点近傍のアスペリティからの寄与が、特に断層直交(FN) 成分において、大振幅のパルスとなって現れることがわかる。 


\section{4. 被害関数}

解析領域が広域にわたり、かつシナリオの数が大量である今回のシ ミュレーションの場合、長戸.川瀬 ${ }^{6)-8)}$ が求めた実耐力分布を反映した 建物モデル群の非線形応答解析に基づいて被害を予測することは大き な計算負荷となる。これは長戸・川瀬モデルでは、1 地点につき 1 建物 種別毎に 12 棟の建物群の応答解析を行なう必要があり、その建物種別 も 15 種類に及ぶからである。この計算負荷を軽减するため増田・他 (2000) ${ }^{12)}$ の作成した長戸・川瀬モデルの予測被害に適合した被害関数 も用いて簡便に被害を予測し、精算解と比較することとした。増田・他 (2000) ${ }^{12)}$ では被害関数に用いる地震動強度指標として、確率紙上での相 関性および兵庫県南部地震の被害再現性に基づいて、最大加速度と最大 速度を掛け合わせた PGA*PGV もしくは計測震度(河角の式で震度を計算 する前のフィルター波の最大加速度 $\mathrm{A}_{0}$ )を用いることを推奨している。そ の被害関数を図 12〜14 に示す。ここでPGA*PGV はパルス幅あたりのエ ネルギーに相当する物理量であり、 $\mathrm{A}_{0}$ とよく対応寸る ${ }^{22}$ 。

なお、長戸・川瀬の被害予測建物群モデルもそれに基づいた被害関数 も、兵庫県南部地震の神戸市域の観測被害率から求めたもので、それを 熊本地方の建物に適用してよいかという所謂地域性の問題はある。それ については最近耐震診断の際に得られる Is 值を地域係数 0.9 の地域と 1.0 の地域で比較したところ、有意な差はなかったことが報告されている ${ }^{21}$ 。
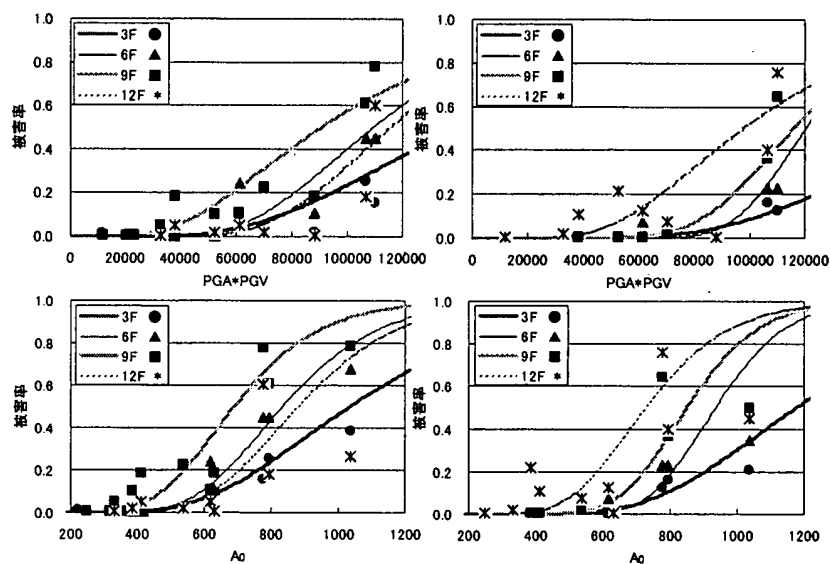

図 12 長戸・川瀨モデルから粠築した RC 造建物の被害関数 左 : 旧耐震(1981 年以前) 右 : 新耐带(1981 年以前)
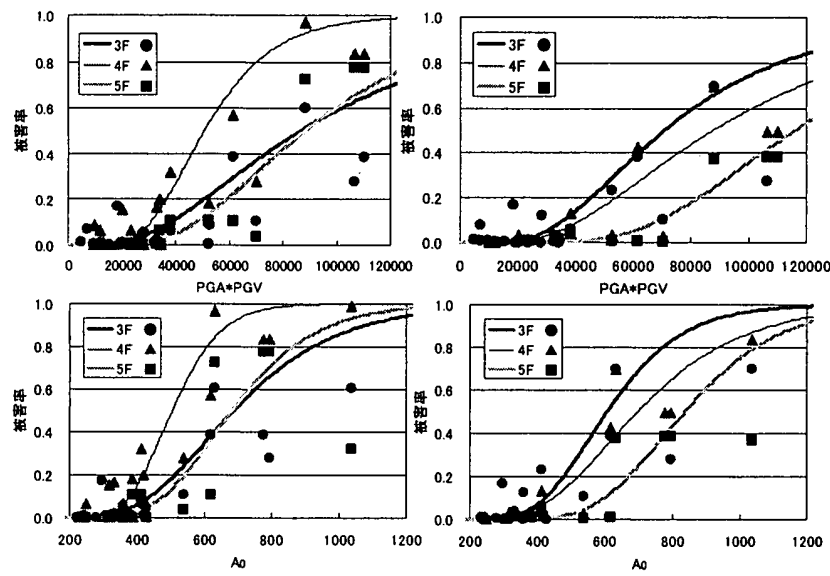

図 13 長戸・川瀬モデルから構筑した鉄骨造建物の被害関数 左 : 旧耐震(1981 年以前) 右 : 新耐震(1981 年以前)

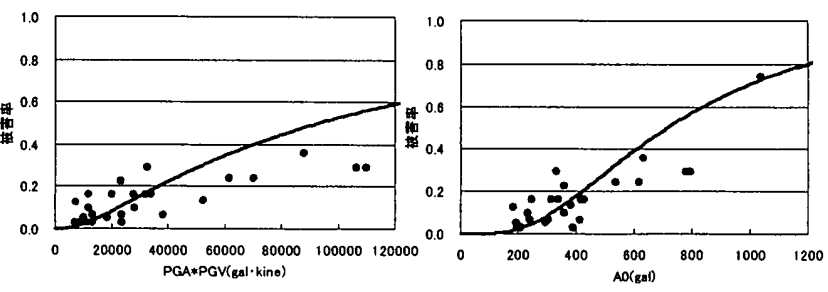

図 14 長戸・川瀬モデルから構築した被害関数 木造物被害関数 年代区分なし

\section{5. 被害予測結果}

ここでは熊本および八代平野において最も広い範囲で高い地震動 レベルが得られた Scenario3 を中心に被害予測結果を示す。まず予 測強震波形を入力とし、長戸・川瀬モデルで $400 \mathrm{~m}$ 間隔の格子上の各 点において 12 棟の耐力の異なる建物について非線形応答解析 ${ }^{6)-8)}$ をし、各建物種別ごとの被害率分布を計算した。その結果を図 15 に示す。一方、同じ予測強震動波形の最大值指標 $\left(\mathrm{PGA}{ }^{*} \mathrm{PGV}\right.$ および $\mathrm{A}_{0}$ )を被害関数に入力し、建物種別ごとの被害率を求め比較した（図 16・図 17)。ここで RC 造と鉄骨造建物については、最も数が多いと 予想される旧耐震 $3 \mathrm{~F}$ 建 (2 階建〜 4 階建を代表する)の計算結果のみ を示す。 $\mathrm{RC}$ 造を除いて、かなりの被害が見られる。特に木造建物で は、八代平野において、断層近傍であること、破壊が進行する方向 で地震波が重なり合うことによって振幅が増大するディレクティビ ティの影響をまともに受けること、および盆地端部で生成される盆 地生成表面波と回折波が下方から伝播してきた $\mathrm{S}$ 波と增幅的干涉を 起こすことによって「エッジ効果」が生じることから、計測震度で も見ても 6.5 以上の領域が生じており、その広い範囲で木造家屋が $20 \%$ 以上倒壊するという結果となっている。これに比べると熊本市 内では最大アスペリティ No. 4 の影響から、計測震度で 6.0 以上の領 域が一部に生じているものの、その予測被害レベルはかなり小さい。

図 15 と図 $16 \cdot$ 図 17 から、 $\mathrm{RC}$ 造・鉄骨造では被害関数の予測はや や過大であることがわかる。これは図 12 ・図 13 に示したように、 被害関数構築の際のデータに大きな被害を出せる地震動が相対的に 少なく、同定された関数が外挿傾向となっていることに起因するも のと推定される。長戸・川瀬モデルの予測被害率によりフィットさ せるためにはここで計算した予測強震動を含む大振幅記録を用いて 被害関数を再構築する必要がある。長戸・川瀬モデルを用いた被害 関数の構築においては、そのようにリアリティのある大振幅入力を 用いて、広い被害レベルまで有効な被害関数を求めることが可能で ある。しかし、通常の実被害から求める被害関数ではその予測範囲 の上限は実被害レベル、すなわち高々 $30 \%$ 程度に留まるので、ここで 見られたのと同様の外挿に伴う誤差の問題が生じるものと推定され る。なお、増田・他の被害関数から推定した被害率と長戸・川瀬モ デルで計算された被害率の相関係数を求めると、それぞれ 3 種類の 建物に対して表 1 のようになり、増田・他の提案した被害関数の適 応性もある程度は確保されていることがわかる。またその適応性は $\mathrm{PGA}^{*} \mathrm{PGV}$ と $\mathrm{A}_{0}$ でほとんど優劣つけ難いことがわかる。なお、建物 種別ごとのデータへの適合度(バラツキ)を見ると図 12 の RC造より も図 13 の鉄骨造の方が適合度は低めとなっている。一方相関係数 

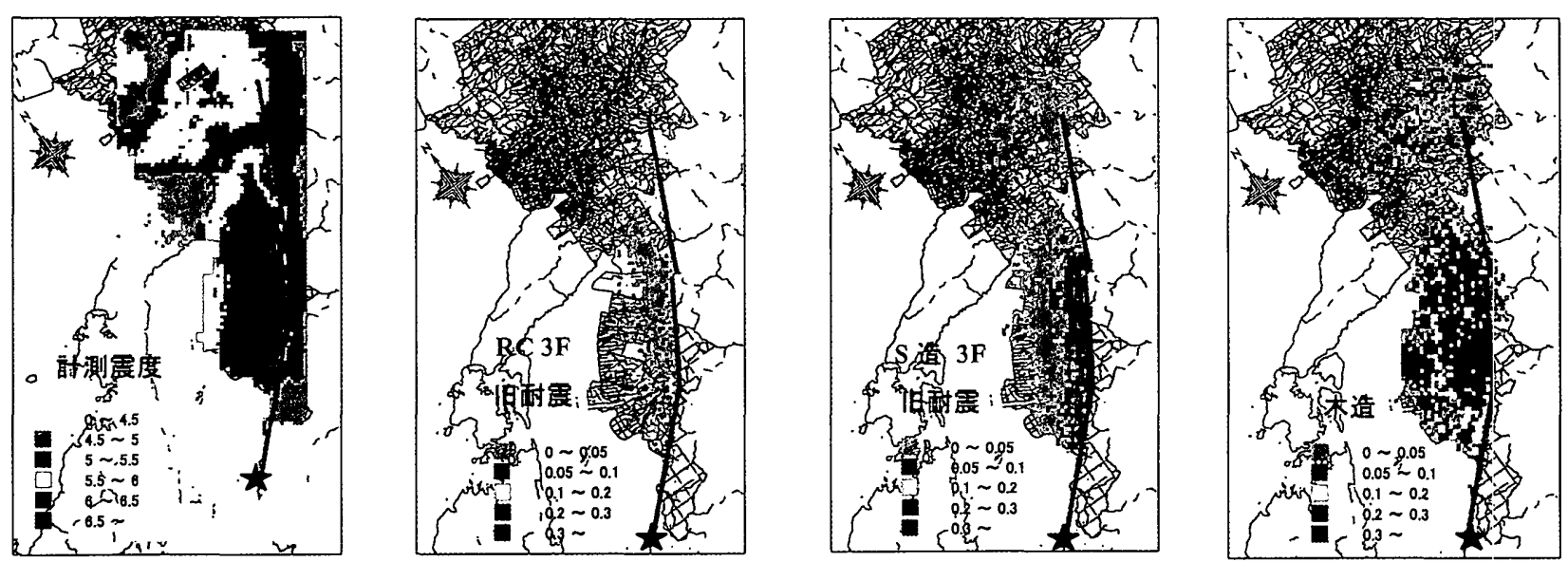

図 15 長戸川瀨モデルで予測した Scenario3 の被害率分布（一番左は計測震度分布）
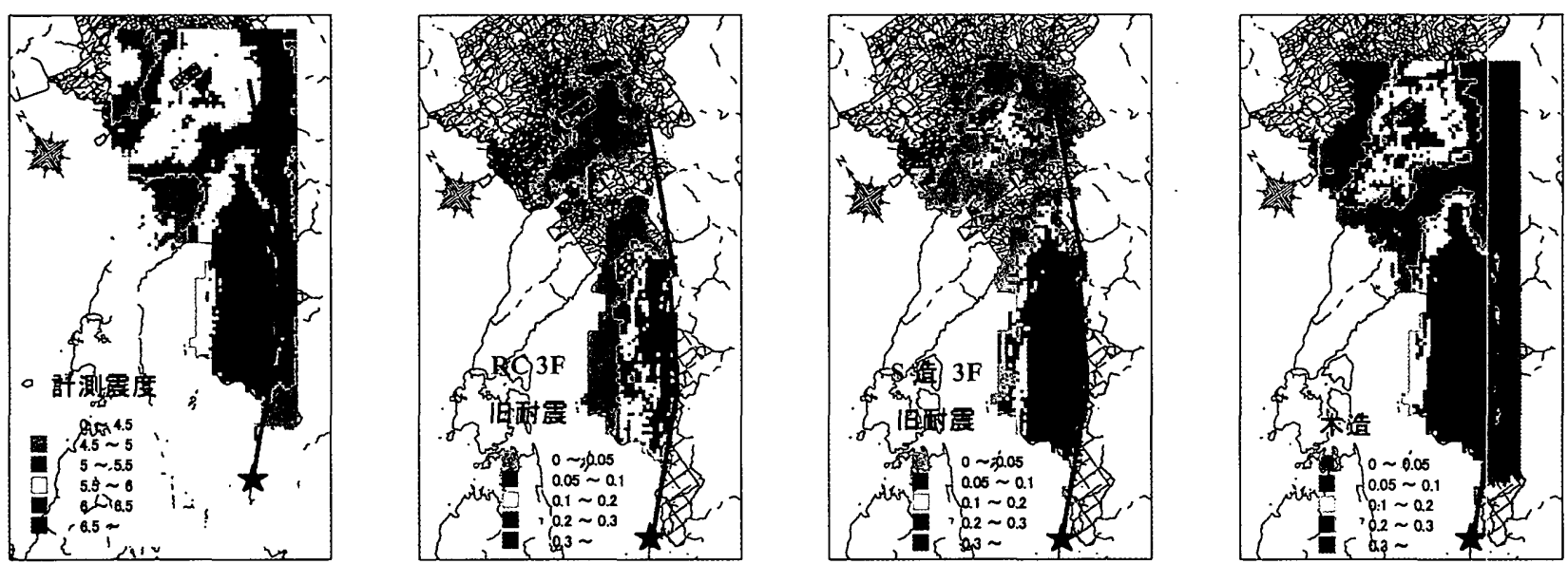

図 $16 \mathrm{~A}_{0}$ を指標とする被害関数で予測した Scenario3 の被害率分布 (一番左は計測震度分布)
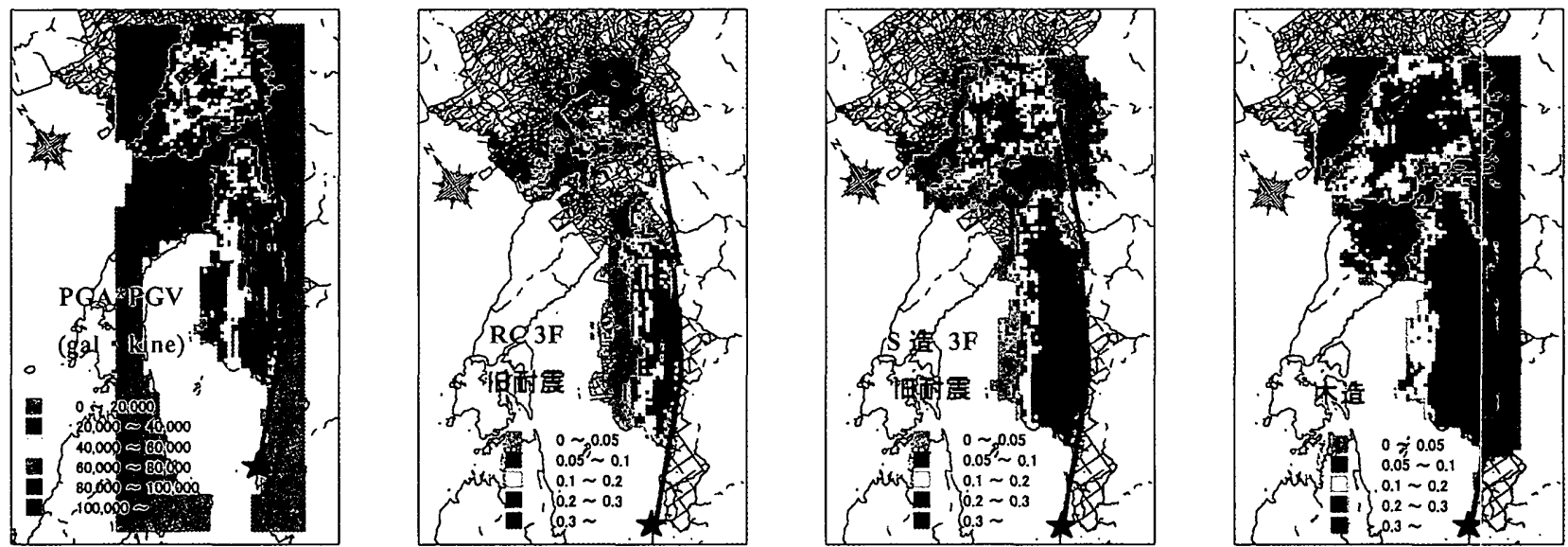

図 17 PGA*PGV を指標とする被害関数で予測した Scenario3 の被害率分布 (一番左は PGA*PGV 分布) 

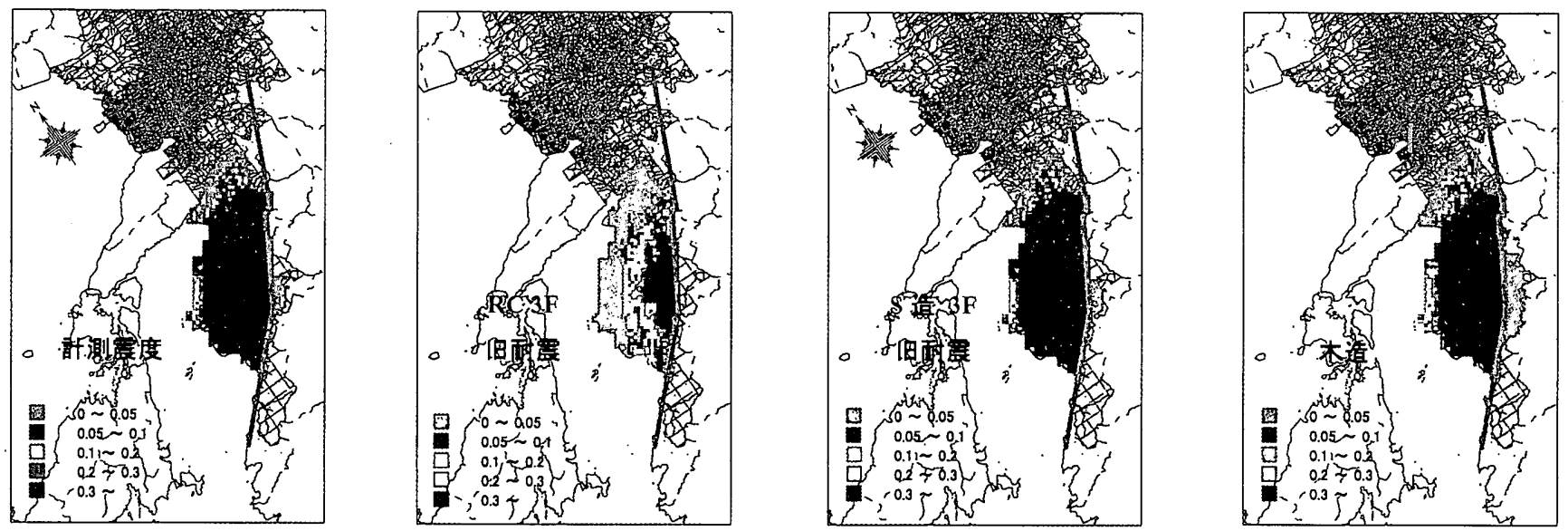

図 $18 \mathrm{~A}_{0}$ を指標とする被害関数で予測した Scenario1の被害率分布 (一番左は計剆殖度分布)
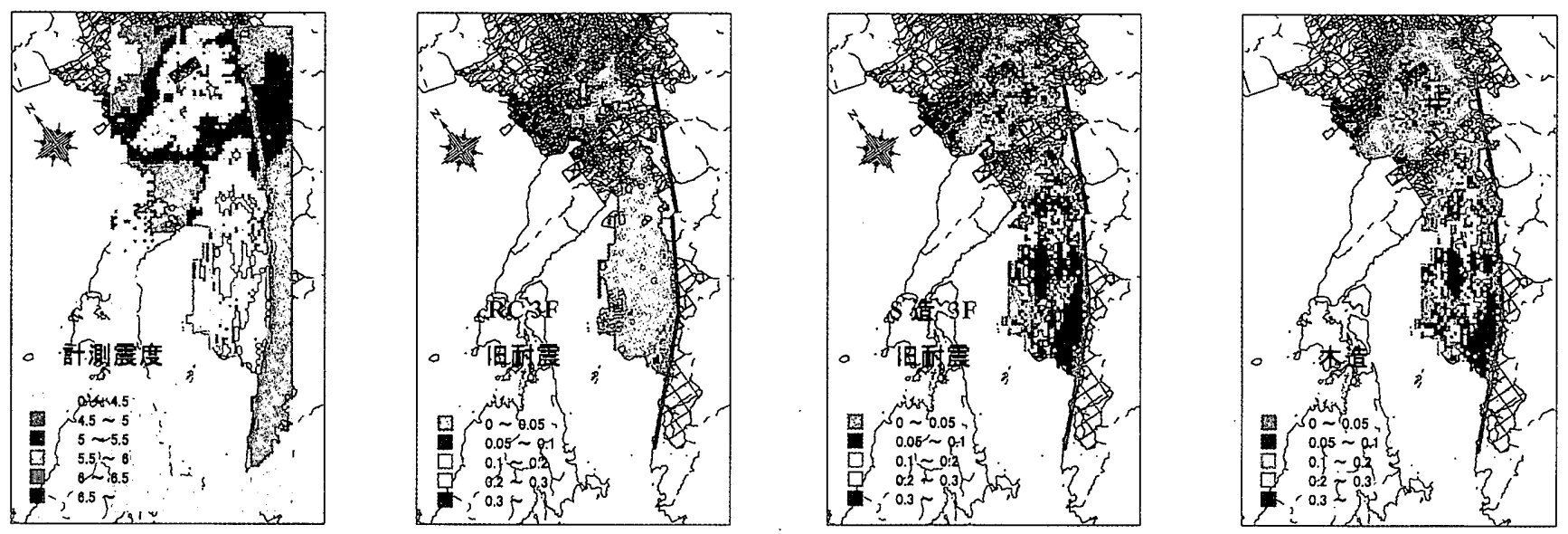

図 $19 \quad A_{0}$ を指標とする被害関数で予測した Scenario11 の被害率分布 (一番左は計測震度分布)

は RC 造の方が低くなっており、必ずしもデータに対する適合度だけ では被害関数の精度が論じられないことがわかる。木造建物の相関 が良好な点を考え合わせるとむしろデータ点数が豊富な場合には良 好な関数が同定されるのではないかと推察され、今後詳細に検討し たい。

\section{表 1 被害率分布の相関係数}

\begin{tabular}{|c|c|c|c|}
\hline 地急動強度指唄 & RC造3F 旧耐震 & 鉄胃造3F 旧耐国 & 木造 \\
\hline 到測唇 $(A 0)$ & 0.566 & 0.730 & 0.877 \\
\hline PGA*PGV & 0.582 & 0.739 & 0.814 \\
\hline
\end{tabular}

図 18 には震源が松島・川瀬モデルと同じScenario1 の予測被害率 ( $A_{0}$ 被害関数による)結果を、図 19 には同じくScenario3に縦ずれ成 分を考えたScenario11 の結果を示す。図 18 からアスペリティが密 集している場合は被害も集中すること、図 19 から繸ずれ成分がある 場合アスペリティ近傍のみで被害が大きくなることがわかる。

\section{6. まとめと今後の課題}

本研究では、九州地方では今のところ発生確率が最も高く、発生 した場合にはその規模も大きな活断層である熊本県日奈久断層に対 して、複数の震源破壊シナリオを考え、強震動を最も精度よく予測 でき、その妥当性が既に検証されているハイブリッド法により深部 および浅部地盤構造の影響を考慮して強震動波形を予測し、非線形 応答解析モデルとそれから構築した被害関数に基づいて熊本・八代 地域の建物の地震被害を予測した。ここでは示さなかった他のシナ リオについては、多くの場合熊本平野での被害はScenario3よりは 少ないものの八代平野においては同程度か、場合によってはアスペ リティの近傍でより大きな被害率が予測されている。またすべり角 に縦ずれ成分を与えた場合には、アスペリティ近傍の最大速度振幅 が純横ずれの場合に比べ大きくなるが全体の被害分布としては大振 幅領域が限定されるので逆に小さくなることがわかった。

本論文で明らかになったように、八代平野は断層近傍にあり、兵 庫県南部地震の際の神戸市のように、断層の破壊伝播に伴う「ディ 
レクティビティ効果」および盆地端部での波動干渉による「エッジ 効果」の影響を大きく受ける可能性が高い。従って八代市東部地域 の断層近傍においては、日奈久断層地震の発生に備えた十分な地震 防災対策が必要であると考えられる。寒際には八代平野の断層側端 部はそれほど都市化されておらず、神戸市のような大規模な建物被 害の集中は起こらないものと考えてよいが、耐震化対策においては これらディレクティビティおよびェッジ効果の影響を考慮した合理 的な判断が重要である。

今後は、大入力時の被害関数の精度を向上させて簡便に、しかし 高精度に広域の被害予測ができるようにするとともに、この地域の 実在建物ストックを調査して想定すべき被害の全貌を明らかにして いきたいと考えている。

今回行った物理モデルに基づいた一連の被害予測手法は、震源プ ロセスや地盤構造、被害予測計算のそれぞれの段階において、多く のパラメターを必要としている。我々のアプローチは物理モデルに 基づくものであるので、そのパラメターは明解に規定されており、 より確度の高い情報が得られればいつでもそれを反映させることが 可能である。現在用いているモデルはそのパラメターの多くを兵庫 県南部地震での観測事実や解析結果から得ているが、我々はモデル の開発と平行して検証作業も鳥取県西部地震 ${ }^{22)}{ }^{23)}$ や台湾集集地震 24)などを対象に行ってきており、それらの地震においても観測事実 と対応する結果が得られている。しかし、今後とも検証作業を通し て必要があれば随時新たな情報を強震動予測モデルや被害予測モデ ルに反映していきたい。

\section{謝辞}

本研究には Robert Graves 博士の FDM コードを使わせて頂いた。 また熊本・八代地域のボーリング情報は田尻雅則氏 (双葉工務店)を 通して (社) 熊本県地質調查業協会より借用した。記して感謝の意を 表する。なお本研究は文部科学省振興調整費「地震災害軽減のため の強震動予測マスターモデルに関する研究」(研究代表者 : 入倉孝次 郎)の研究資金によって実施したものである。

\section{参考文献}

1）入倉孝饮郎・釜江克宏：1948 年福井地震の強橆動ーハイブリッド法によ る広周期带域强震動の再現，地震，第 2 輯，第 52 巻，129-150, 1999.

2）川瀬博・松島信一：半経験的方法・理論的方法およびそれらのハイブリ ッド合成法に上る強震動評価一兵連県南部地震の場合一, 日本建築学会 大会学術講演梗概集 B2，171-172，1998.9.

3）佐藤俊明・壇一男：1923 年関東大地震 $(M s=8.2)$ の断層の非一様すべり破 㙏を考虑した 3 次元差分法と半経験的波形合成法のハイブリッドによる 東京に扔ける広带域強震動シミュレーション, 日本建築学会大会学術講 演梗概集 B2，173-174，1998. 9 .

4）早川崇：名古屋市における強震動予測事例，一澄尾平野の 3 次元堆皘盆 地モデルの作成と適用一, 地盤震動シンポジウム, 日本建築学会地盤震 動小委員会, 2003. 10.

5）中道聡・川瀬博：福岡市における三次元地下構造を考虑したハイブリッ ド法による広周期带域強震動予測，日本建築学会構造系論文集，560， 83-91，2002. 10.

6）長戸健一郎・川瀬博： 建物被害データと再現強震動による RC 造建物群 の建物予測モデル，日本建築学会構造系論文， 544，31-38，2001.6.

7）長戸煡一郎・川瀬博：鉄骨造建物群の被害予測モテルの構築，日本建築 学会構造系論文集，559，101-106，2002.9.

8）長戸健一郎・川瀨博：観測被害統計と非線形応答解析に基づく木造建物 被害予測モデルの構築と観測強震動への適用，第 11 回日本地震工学シ
ンポジウム, 2002.11.

9）川瀨博・長戸健一郎・中道聡：ハイブリッド法強震動予测結果に基づ いた福岡市におけるシナリオ地震の被害予测, 構造工学論文集, Vo1. 49B, 2003.3.

10）地霞謂查研究推進本部，布田川・日奈久断層带の評価， http://www. jishin. go. jp/main/chousa/02may_futagawa/index. htm, 2002. 5. .

11）松島信一・川瀬博：1995 年兵庫県南部地震の複数アスペリティモデル の提案とそれによる強震動シミュレーション, 日本建築学会構造系論文 集，534，33-40，2000.8.

12）増田有周・長戸健一郎・川瀬博： $\mathrm{RC}$ 造建物の地震応答解析結果に基づく 被害関数構築に関する研究, 日本建築学会構造系論文集，558，101-107， 2002.8.

13）活断層研究会：[新編]日本の活断層 分布図と資料, 東京大学出版会 1995.5

14）時松孝次・新井洋・浅香美治：微動観測から推定した神戸市住吉地区の 深部 S 波速度構造と地震動特性, 日本建築学会構造系論文集， 491， 37-44, 1997. 1 .

15) Satoh, T., H. Kawase, T. Sato, and A. Pitarka : Three-dimensional finitedifference waveform modeling of strong motions observed in the Sendai Basin, Japan, Bulletin of the Seismological Society of America, 91, 812-825, 2001.

16）川瀨博・原田裕之： K-NET 観測データから求めた $\mathrm{P}$ 波, $\mathrm{S}$ 波, coda 波の $\mathrm{H} / \mathrm{V}$ スペクトル比と地盤増幅特性との関係, 日本建築学会大会学術講演 梗概集, B-2 分冊, p. 47, 2002.8.

17）防災科学技術研究所：基媻強震観測網 KiK-net, http://wWw. kik bosai.go.jp/kik, 1997. 6 .

18）地震調查研究推進本部：布田川・日奈久断層帯の地震を想定した強震動 評 価について, http://www.jishin. go.jp/main/kyoshindo/ 03 jul_futagawa/index. htm, 2003.7.

19）伊藤茂郎・久原䙾之・川瀬博：K-net データから抽出した地震動の統計 的性質とそれを用いた波形合成用グリーン関数の生成, 日本建築学会構 造系論文集，543，37-44，2001.

20) Graves, R.W. : Simulation Seismic Wave Propagation in 3D Elastic Media Using Staggered-Grid Finite Differences, Bulletin of the Seismological Society of America, 86, 1091-1106, 1996.

21）高橋雅人 - 澤田幸司 - 藤井賢志 - 中埜良昭 - 真田靖士 - 岡田恒男：既存 鉄筋コンクリート造学校建築の耐震診断・耐震補強事例の分析, 第 11 回日本地震工学シンポジウム論文集, 2002.11.

22）川瀬博・長戸健一郎：鳥取県西部地震の震源域で観測された強震動とそ の構造物破壊能, 日本建築学会研究報告九州支部, 第 40 号・ 1 構造 系, 221-224, 2001 .

23）斎藤裕輔・川瀬博：理論的グリーン関数を用いた鳥取県西部地震の震源 モデルの構築，日本建築学会九州支部研究発表会梗概集，第 42 号・1 構造系, 253-256, 2003.3.

24）川瀬博：震源近傍における入力地震動評価，第 28 回地盤:震動シンポジ ウム, 震源近傍の強震動と設計用入力地震動, 一トルコ・コジャエリ地 震，台湾・集集地震の経䀫を蹨まえて一，日本建築学会，85-96，2000。 